\title{
ON THE SPECIES OF THE GENUS MIRAX FOUND IN NORTH
} AMERICA.

BY WM. H. ASHMEAD, WAShINGTON, D. C.

No species in the genus Mirax is yet described from the United States, although in Insect Life, v. 3, p. 15, $\mathrm{I}$ have indicated three species in Ms. reared by Dr. Riley at the Department of Agriculture.

In Europe, only a single species appears to be known, viz., Mirax spartii Haliday, the type of the genus, parasitic on Nepticula septembrella Stainton, a Tineid found mining the leaves of St. John's Wort, Hypericum perfoliatum.

The habits of our species conform to the European species, in that they are parasitic on the Tineina.

Species black, base of abdomen pale.

Scutellum polished.

Three basal abdominal segments pale; second flagellar joint about as long as the first.

Stigma brownish-yellow; legs yellowish sometimes tinged with fuscous, the articulations pale ; first submarginal and first discoidal cells confluent.

M. aspidiscae.

Stigma fuscous; legs brownish-yellow, the tarsi fuscous; first submarginal and first discoidal cells distinctly separated.

M. minuta.

Scutellum finely punctate.

Stigma pale brownish; hind tarsi fuscous ; first submarginal and first discoidal cells not entirely separated.

Antennae longer than body, the 7 terminal joints $2 \frac{1}{2}$ times as long as thick. . . . . . M. lithocolletidis.

Antennae longer than body, the joints after the $3^{\text {rd }} 4$ times as long as thick; all femora and the hind tibiae and tarsi tinged with fuscous.

M. grapholithae. Wholly brownish-yellow, all tarsi fuscous. . . . . M. pallida. 
I. M. aspidiscae sp. n. ₹ क.-Length $\mathrm{I} .3$ to $1.5 \mathrm{~mm}$. Black, shining, but microscopically punctulate, pubescent; two basal joints of antennae and sometimes base of the third and legs brownish-yellow; sometimes more or less of the femora, especially toward base, posterior tibiae and tarsi fuscous or dusky in female; abdomen, in female with three basal segments pale, in male with only two, oval, black or brown-black. Antennae 14-jointed, as long as the body, the flagellar joints very gradually subequal after the second, the first and second the longest, about equal. Thorax without furrows, the scutellum polished, the metanotum with a median carina. Wings hyaline, the stigma and nervures pale brownish yellow, the first submarginal and first discoidal cells confluent.

Hab.-United States.

Types in National museum and Coll. Ashmead.

This species seems to be a common parasite on Aspidisca splendoriferella Clem., a small case bearing Tineid on apple. Those in the National museum were reared in 1879 , and the same is figured in Prof. Comstock's Report for the same year, pl. 2, fig. 2, $h$. My specimens were reared from this Tineid in 1888 .

2. M. minuta sp. n. $q$.-Length $\mathrm{I} \mathrm{mm}$. Black, shining, faintly pubescent; flayellum brown-black, slightly incrassated toward the tip, the 7 terminal joints short, scarcely twice as long as thick; scape, pedicel, three basal abdominal segments and the legs, including all the coxae, yellow; tarsi fuscous.

Wings hyaline, the stigma fuscous, otherwise the venation pale yellow; the first submarginal and first discoidal cells distinctly separated.

Hab.-Jacksonville, Florida.
Types in Coll. Ashmead.

Comes closest to $M$. aspidiscae, but its smaller size and the distinctly separated first submarginal and first discoidal cells readily distinguish the species.

3. M. lithocolletidis sp. n. \& \&.-Length I. 5 to $1.6 \mathrm{~mm}$. The head and thorax feebly rugose or punctulate, subopaque. Antennae filiform, I4-jointed, longer than the body, pubescent; scape beneath and pedicel at apex and beneath, yellowish; flagellum black or brown black, the joints to the last subequal, the last longer than the preceding; metanotum with a grooved line at the middle; face, basal half of abdomen and legs yellow or brownish yellow; hind tarsi fuscous. Wings hyaline, the costa and stigma fuscous, the other nervures yellowish; the first submarginal and the first discoidal cells not entirely separated. The first and second abdominal segments have a central longitudinal carina or fold.

In the male, the head, thorax and apical half of abdomen are fuscous, while the orbits (broadly), lower part of cheeks, the face, basal half of abdomen, and the legs are yellow.

Hab.-Washington, D. C. and Jack sonville, Florida.

Types in National museum and Coll. Ashmead.

The single specimen in the National museum was reared from a Leaf-miner on locust, Lithocolletis ornatella Chambers,

4. M. grapholithae sp. n. J.-Length $1.5 \mathrm{~mm}$. Head and thorax black, shining, although finely punctate and sparsely sericeous. Abdomen brownish-piceous, blackish towards apex, pale yellowish towards base; legs pale brown, the femora towards base and hind tibiae and tarsi, dusky or fuscous. 
Head transverse, very little broader than the thorax, the occiput emarginate at middle, the cheeks margined; face below the antennae, prominently convex, shining, with sparse whitish hairs; clypeus separated, subconvex; mandibles piceous; palpi brown, the maxillaries very long. Antennae I4-jointed, longer than the body, setaceous, brown, the scape and pedicel yellowish; scape not quite twice as long as the pedicel; flagellum slender, cylindrical, the joints very slightly subequal, after the $3^{\text {rd about }} 4$ times as long as thick. Metanotum with a median sulcus bounded by carinae. Wings hyaline, the stigma and nervures pale brown.

Hab.-Washington, D. C.

Type in National museum.

The single $\hat{\sigma}$ specimen was reared May 3, I88I, from Grapholitha prunivora Walsh.
5. M. pallida sp. n. \&.-Length $2 \mathrm{~mm}$. Brownish-yellow, minutely closely punctulate. Antennae I4-jointed, fuscous toward tips, flagellar joints $I$ and 2 about equal, as long as the two last joints united, joints 3 and 4 about the length of the 2 nd, those beyond gradually become shorter, subequal. Eyes brown, subpubescent. Mesopleurae smooth. Metanotum with a distinct median carina. Wings hyaline, the stigma and nervures brownish yellow. Abdomen oval, as long as the thorax, the first segment with a narrow linear shield, the membranaceous margins broad; ovipositor as long as the basal tarsal joint in hind legs. All tarsi more or less fuscous.

Hab.-Jacksonville, Florida.

Type in Coll. Ashmead.

The large size and pale color readily distinguish the species.

\title{
NOTES ON THE LARVAL STAGES OF ARCTIA BLAKEI Grote.
}

\author{
BY HARRISON G. DYAR, BOSTON, MASS.
}

Euprepia (Cymbalophora) blakei Grote. I863-Grote, Proc. ent. soc. Phil., iii, 523. Arctia.

1874-Stretch, Zyg. Bomb. N. A., 224. I $892-$ Kirby, Cat. Lep. Het., i, 267. Apantesis.

superba Stretch.

I874-Stretch, Zyg. Bomb. N. A., 227.

geneura Strecker.

I 878-Strecker, Proc. Dav. acad. sci., ii, 270.

I884-French, Papilio, iv, I 58.

1889-French, Can. ent., xxi, 162 .

incorrupta $\mathrm{Hy}$. Edwards.

I881-Hy. Edw., Papilio, i, 38 .

shastaensis Behrens.

1889-French, Can. ent., pp. 35 and 162.

var. NEVADENSIS Grote and Robinson.

I 866-Grt. and Robs., Proc. ent. soc. Phil., vi, i Arctia.
I886-Grote, Can. ent., xviii, Io9.

I892-Kirby, Cat. lep. Het., i, 268. Apantesis.

behrii Stretch.

I872-Stretch, Zyg. Bomb., N. A., 75.

var. SUlPHURICA Neumoegen.

1885-Neum., Ent. amer., i, 93.

elongata Stretch.

I885-Stretch, Ent. Amer., i, IO5.

I892-Kirby, Cat. lep. Het. i, 270.

ochracea $\|$ Neum.

I883-Neum., Papilio, iii, I5r.

In Kirby's catalogue the American species, formerly referred to Arctia, are distributed irregularly under three generic names. As the species do not seem to be separable generically, I adopt the oldest name for the genus, viz. Euprepia Ochs. (1810), under which name are found $E$. pudica Esp. and $E$. fasciata Esp. Arctia Schrank is restricted 



Submit your manuscripts at

http://www.hindawi.com
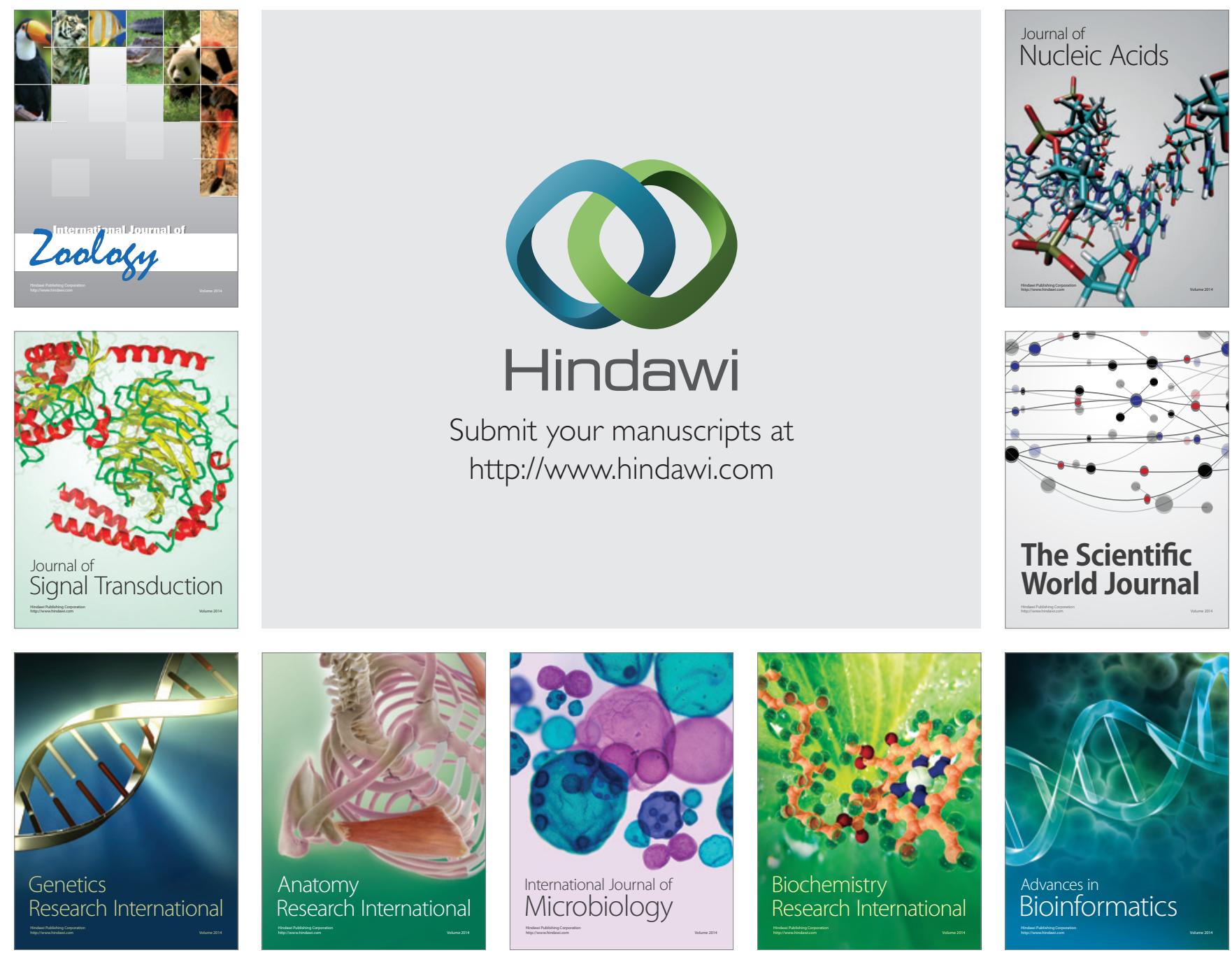

The Scientific World Journal
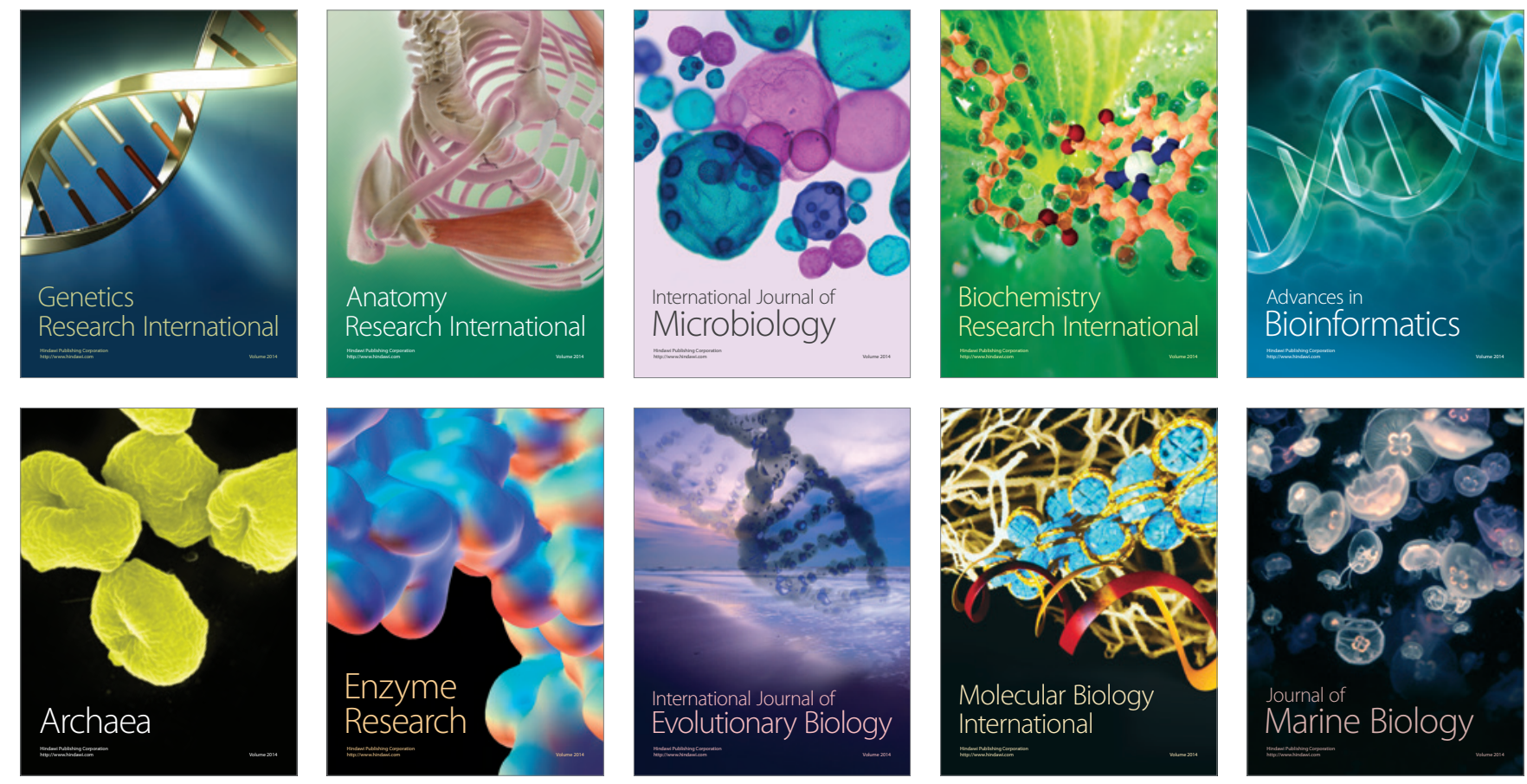